\title{
Rheological and structural properties of differently acidified and renneted milk gels
}

\author{
X. T. Liu, ${ }^{* 1}$ H. Zhang, ${ }^{* 1}$ F. Wang, † J. Luo,† H. Y. Guo,ł and F. Z. Ren*2 \\ ${ }^{*}$ Beijing Laboratory of Food Quality and Safety, College of Food Science and Nutritional Engineering, China Agricultural University, \\ Beijing 100083, China \\ †Key Laboratory of Functional Dairy, College of Food Science and Nutritional Engineering, China Agricultural University, Beijing 100083, China \\ $\ddagger$ Beijing Higher Institution Engineering Research Center of Animal Product, Beijing 100083, China
}

\begin{abstract}
In this study we assessed the rheological and structural properties of differently acidified and renneted milk gels by controlling $\mathrm{pH}$ value and renneting extent. Skim milk were exactly renneted to 4 extents $(20,35$, 55 , and $74 \%$ ) and then direct acidified to the desired $\mathrm{pH}(4.8,5.0,5.2,5.5,5.8$, and 6.2), respectively. Rheological properties were assessed by dynamic rheological measurements, structural properties were studied by spontaneous whey separation and confocal laser scanning micrograph, and protein interactions were studied by dissociation test. Results showed that minimally renneted milk samples (20 and 35\%) formed weak gels with low storage modulus, and the acidification range within which gels could form was narrow $(\mathrm{pH} \leq 5.2)$. Highly renneted milk samples formed more gels with high storage modulus. The results of this study revealed that acidification determined the structural properties of highly renneted milk gels. As $\mathrm{pH}$ increased from 5.0 to 6.2 , highly renneted milk gels had lower loss tangent, decreased spontaneous syneresis, and smaller pores. For both the low and high rennetings, divalent calcium bonds contributed less at low $\mathrm{pH}$ than at high $\mathrm{pH}$. In conclusion, renneting increased the $\mathrm{pH}$ range suitable for gel formation; acidification determined the spontaneous syneresis and microstructure of highly renneted milk gels.
\end{abstract}

Key words: milk gel, acid, rennet, rheology

\section{INTRODUCTION}

Milk gelation is a crucial step in the manufacture of fermented dairy products and has been extensively studied (Lucey, 2002; van Vliet et al., 2004). Milk gels can be produced by acid or rennet, resulting in gels with different properties (Lucey, 2002). In acid-induced gels,

Received October 6, 2013

Accepted March 3, 2014.

${ }^{1}$ These authors contributed equally to this paper.

${ }^{2}$ Corresponding author: renfazheng@263.net colloidal calcium phosphate (CCP) is released from micelles and net-negative charges are lost with decreasing $\mathrm{pH}$, thereby reducing the electrostatic and steric repulsions and favoring aggregation (Lucey and Singh, 1998). At $\mathrm{pH} 4.8$, milk forms weak gels and shows gelation (Lucey et al., 1997). Hydrophobic, hydrogen, and electrostatic interactions are homogeneously distributed (Lefebvre-Cases et al., 1998). In rennet-induced gels, casein micelles aggregate extensively when more than $85 \%$ of $\kappa-\mathrm{CN}$ is hydrolyzed (Dalgleish, 1979). Hydrophobic interactions and calcium bonds are the main forces in rennet-induced gels (Lefebvre-Cases et al., 1998). Even though acid- and rennet-induced gels have been extensively studied, the gelation behavior of combined acid- and rennet-induced gels are not well understood.

Combined acid and rennet gelation is often used in the manufacture of certain types of cheese to improve gel draining and firmness (Jelen and Renzschauen, 1989). It has also been successfully used in soya milk and skim milk gels (Lin et al., 2012). Because it is an enzyme- and acid-induced process, the gelation behavior is quite complicated and largely depends on coagulation processes (Castillo et al., 2006a; Le Feunteun and Mariette, 2008; Cooper et al., 2010; Salvatore et al., 2011).

In previous studies, rheological and structural properties of combined acid- and rennet-induced milk gels were studied by simulating the coagulation process. Lucey et al. (2000) reported that the concentrations of acidulant and rennet significantly affect gelation behavior. The storage modulus $\left(\mathbf{G}^{\prime}\right)$ of combined acidand rennet-induced gels is higher than strictly acid- or rennet-induced milk gels. Researchers have reported that in partial renneting and continuous acidification, milk gel formation occurs in 2 stages based on the acidification degree $(\mathrm{pH}<5.0$ and $>5.0$; Li and Dalgleish, 2006). Studies about the structural properties of combined acid- and rennet-induced milk gels reported that increasing inoculum levels induces a reduction in syneresis (Castillo et al., 2006b) and calcium release is responsible for the final structure (Salvatore et al., 
2011). Therefore, the combined addition of acid and rennet can lead to different coagulation processes and gel products. However, based on these studies, acid and rennet act continuously and synergistically. The contribution of acid and rennet on gelation and gel properties is not clear. The objective of the current study was to assess how acid and rennet affect the behavior of combined acid- and rennet-induced gels by analyzing the rheological and structural properties.

\section{MATERIALS AND METHODS}

\section{Materials}

Fresh milk, obtained from San Yuan Dairy Co. (Beijing, China), was centrifuged at 4,000 $\times g$ for $20 \mathrm{~min}$ at $25^{\circ} \mathrm{C}$ and skimmed. Sodium azide $(0.02 \% \mathrm{wt} / \mathrm{vol})$ was added to prevent bacterial growth. Skim milk was stored at $4^{\circ} \mathrm{C}$. Rennet (Chr-Max Powder Extra, 2,235 international milk clotting units/g) was supplied by Chr. Hansen Inc. (Hørsholm, Denmark). All chemicals and reagents were of analytical grade. Double distilled water (Millipore, Billerica, MA) was used throughout the experiments.

\section{Preparation of Differently Acidified and Renneted Milk}

As different $\mathrm{pH}$ needs different time to rennet $\kappa-\mathrm{CN}$ to the same hydrolysis, acidification before renneting would make it complex and difficult to control acidification and renneting. Therefore, we acidified after renneting. Controlled renneting was performed at $4^{\circ} \mathrm{C}$ by adding different amounts of rennet previously diluted in water $(1: 50 \mathrm{wt} / \mathrm{vol})$ to skim milk. Four renneted milk samples $(20,35,55$, and $74 \%)$ were prepared by adding different amounts of rennet $(20,40,60$, or $80 \mu \mathrm{g} / 100$ $\mathrm{mL}$ ) to skim milk. After stirring for $1 \mathrm{~min}$, the milk samples were stored at $4^{\circ} \mathrm{C}$ for $12 \mathrm{~h}$. Milk was completely hydrolyzed with $2 \mathrm{mg} / 100 \mathrm{~mL}$ rennet. Renneting degree was determined by comparing the amount of casein macropeptide (CMP) released from different milk samples to that released from completely hydrolyzed milk (Gastaldi et al., 2003; Li and Dalgleish, 2006). The CMP content was determined by reverse-phase HPLC (Shimadzu, Kyoto, Japan) according to an established method (Thoma et al., 2006). Our preliminary results revealed that, as a result of the low rennet concentrations and the quickly direct-acidified gel formation, the renneting degree of the milk samples increased within $2 \%$ during gel formation. This increase, however, is unlikely to significantly affect the gel properties.

To control acidification, we used a direct acidification method, which keeps $\mathrm{pH}$ values constant (Roefs and van Vliet, 1990; Roefs et al., 1990; Hammelehle et al., 1997). The 4 renneted milk samples were acidified at $4^{\circ} \mathrm{C}$ to 6 different $\mathrm{pH}$ values: $4.8,5.0,5.2,5.5,5.8$, or 6.2. In this experiment, $\mathrm{pH}$ was determined using a $\mathrm{pH}$ meter (YM Instrument Co., Jiangyan, China). The rate of acid addition was regulated with a constant flow pump (Qinpu Huxi Instrument Co., ShangHai, China); the $\mathrm{pH}$ values were controlled within \pm 0.02 . Particle size analysis confirmed that acidification with lactic acid $(2 \% \mathrm{vol} / \mathrm{vol})$ at $1 \mathrm{~min} / \mathrm{mL}$ was adequate because it did not lead to a significant increase in casein micelle size.

\section{Gel Formation and Dynamic Rheological Measurements}

The acidified and renneted milk samples were transferred to a rheometer (AR1500 rheometer, TA Instruments Ltd., New Castle, DE) equipped with a 60-mm diameter plate. All samples were treated under the same conditions and the temperature was risen to $32^{\circ} \mathrm{C}$ in $5 \mathrm{~min}$ by the controlled heating system. The $\mathrm{G}^{\prime}$ and loss tangent ( $\tan \delta$ ) were continuously measured. A cover was placed on the cylinder to prevent evaporation. Dynamic rheological measurements were performed to monitor the gelation process at $32^{\circ} \mathrm{C}$. The measurements were performed at $1 \mathrm{~Hz}$ and $0.1 \mathrm{~Pa}$ of applied stress, which was within the linear viscoelastic region. Gelation point was defined as the point when gels had a $\mathrm{G}^{\prime} \geq 1 \mathrm{~Pa}$ (Lucey et al., 2000; Castillo et al., 2006a). The effect of the time scale of deformation on the rheological properties was determined by frequency sweep after $1 \mathrm{~h}$ of acidification. Frequency varied from 0.01 to $1.0 \mathrm{~Hz}$.

\section{Spontaneous Whey Separation}

Spontaneous whey separation was determined by volumetric flask experiment (Lucey et al., 1998). Following acidification, milk samples were filled below the volumetric flask neck and heated in a bath water to $32^{\circ} \mathrm{C}$. After $2 \mathrm{~h}$, the volumetric flasks were examined. Whey separation was expressed as the ratio of whey separated from the gels to the initial weight of the milk sample. Experiments were repeated 8 times.

\section{Confocal Laser Scanning Microscopy}

The microstructure of milk gels was examined under a Leica TCS SP2 confocal scanning laser microscope (Leica Microsystems CMS GmbH, Mannheim, Germany). Following acidification, $1 \mathrm{mg} / \mathrm{mL}$ of rhodamine $\mathrm{B}$, a fluorescent dye, was added. After stirring for $1 \mathrm{~min}, 100$ $\mu \mathrm{L}$ of the milk sample was placed in a concave slide. A 
cover slide was placed over the sample and sealed. Each slide was placed in a Petri dish and equilibrated to $32^{\circ} \mathrm{C}$ in a water bath. The confocal scanning laser microscope was used in fluorescence mode with a $63 \times$ oil-immersion objective. An $\mathrm{Ar} / \mathrm{Kr}$ laser was used as a light source at $568 \mathrm{~nm}$. The micrographs were acquired in $512 \times 512$ formats. Only representative images are shown.

\section{Dissociation Test}

Protein interactions were studied using dissociating chemical agents (Lefebvre-Cases et al., 1998; Alessi et al., 2007; Zamora et al., 2012). After heating at $32^{\circ} \mathrm{C}$ for $1 \mathrm{~h}$, gel samples $(1 \mathrm{~mL})$ were dispersed in $4 \mathrm{~mL}$ of dissociating solutions containing $10 \mathrm{~g} / \mathrm{L}$ of SDS, $6 \mathrm{M}$ urea, or $2 \mathrm{~m} M$ EDTA (pH 10.0). For the control samples, gels were mixed with $4 \mathrm{~mL}$ of water. Mixtures were rapidly dispersed (Ultra-Turrax T 25, IKA Labortechnik, Staufen, Germany) at 9,000 rpm for $1 \mathrm{~min}$. Gel dispersions were subsequently ultra-centrifuged (Beckman Optima LE-80K with rotor type $50.2 \mathrm{Ti}$, Beckman Instruments France S.A., Gagny, France) at 86,000 $\times g$ for $30 \mathrm{~min}$ at $25^{\circ} \mathrm{C}$.

The resulting supernatants were carefully separated and analyzed by SDS-PAGE (Laemmli, 1970) using separating and stacking gels containing 14 and 5\% acrylamide, respectively. Molecular weight markers were used as standards. The diluted samples in SDS, urea, EDTA, or water were mixed with sample buffer (60 mM Tris-HCl, pH 6.8, $250 \mathrm{~g}$ of glycerol, $20 \mathrm{~g}$ of SDS, $50 \mathrm{~mL}$ of 2-mercaptoethanol, and $1 \mathrm{~g}$ of bromophenol blue per liter) and heated in boiling water for 5 min. Proteins were stained in R250 Coomassie blue (Sigma-Aldrich Co., St. Louis, MO) and destained with $10 \%$ (vol/vol) methanol and 10\% (vol/vol) acetic acid distaining solution. Destained gels were scanned for qualitatively analysis of protein composition.

\section{Statistical Analyses}

Three replicates were performed for each treatment unless otherwise specified. One-way ANOVA and 2-way ANOVA with an interaction effect were performed to determine significant differences $(P<0.05)$. Differences among multiple means were compared using Duncan's multiple range tests. Independent samples $t$-test was used to compare differences between the 2 means (SPSS version 16.0, SPSS Inc., Chicago, IL). Statistical significance was set at $P<0.05$.

\section{RESULTS AND DISCUSSION}

\section{Rheological Properties}

Storage modulus is a measure of the energy stored per oscillation cycle. A low $\mathrm{G}^{\prime}$ indicates that the strength and number of bonds in a matrix may be low, resulting in breakage (Lucey, 2001). The $\mathrm{G}^{\prime}$ values of milk gels are shown in Table 1. Two-way ANOVA analysis indicated that $\mathrm{pH}$ had a significant effect on the properties of milk gels $(P<0.05)$. Renneting also had a significant influence on the milk gels $(P<0.05)$, and a strong interaction between $\mathrm{pH}$ and renneting was also observed $(P<0.05)$. At $20 \%$ renneting, milk samples had low $\mathrm{G}^{\prime}$ values. At $35 \%$ renneting, the $\mathrm{G}^{\prime}$ value of acidified milk samples ( $\mathrm{pH}$ 4.8) was high. It was reported that equilibrium between electrostatic repulsions and hydrophobic interactions maintains the association of caseins (i.e., as electrostatic repulsions decreases, attraction among caseins increases; Horne, 1998). Therefore, when $\mathrm{pH}$ increased from 4.8 to 5.0 or 5.2, electrostatic repulsions increased and interaction forces decreased, resulting in weak gels. At $55 \%$ renneting, milk samples at $\mathrm{pH} 5.5,5.8$, and 6.2 formed strong gels with high $\mathrm{G}^{\prime}$ values, but milk samples acidified to $\mathrm{pH} 4.8$ had low $\mathrm{G}^{\prime}$ values. These results could be attributed to the strong interactions among casein molecules as a result of released CMP and dissolved CCP (de Kruif, 1999; Le Graët et al., 1999). When $55 \%$ renneted milk samples were acidified to $\mathrm{pH}$ 5.0 or 5.2, dissolved CCP reduced casein cross-linking and increased repulsion among the newly exposed phosphoserine residues, resulting in flocculation and weak gel structures (Choi et al., 2007). The $\mathrm{G}^{\prime}$ values of $74 \%$ renneted milk samples were similar to those of $55 \%$ renneted milk samples. This indicated that the strength of interactions between particles to aggregate together were similar in both cases.

Loss tangent is the ratio between viscosity and elastic modulus; higher tan $\delta$ values facilitate a rearrangement in the gels (Lucey and Singh, 1998; Lucey, 2001). The $\tan \delta$ values of milk gels at $1 \mathrm{~h}$ are shown in Table 2 . At 20 and $35 \%$ renneting, $\tan \delta$ values of milk gels at $\mathrm{pH}$ 4.8 were lower than the others $(P<0.05)$. This result suggested that acidification resulted in more elastic milk gels. At 55 and $74 \%$ renneting, $\tan \delta$ of milk gels decreased as $\mathrm{pH}$ increased from 5.0 to 6.2. This result indicated that acidification resulted in more viscous milk gels. Similar results were obtained with $74 \%$ renneted milk. These results suggested that the effect of $\mathrm{pH}$ on $\tan \delta$ depended on the level of renneting. As renneting level increased, gelation $\mathrm{pH}$ increased as well. At 20 and $35 \%$ renneting, the gelation $\mathrm{pH}$ was $\leq 4.8$ and $\leq 5.2$, respectively, but the $\mathrm{pH}$ of the milk samples were 4.8 to 6.2 . Under these conditions, acidification contributed to a faster rearrangement of strands and micelle aggregation (Zoon et al., 1989), whereas at 55 and $74 \%$ renneting the $\mathrm{pH}$ was already below the gelation $\mathrm{pH}$ and the removal of CCP from the gel structure led to more viscous gels (Anema, 2009). 
Table 1. Storage modulus (Pa) of differently acidified and renneted milk gels at $1 \mathrm{~h}^{1}$

\begin{tabular}{|c|c|c|c|c|}
\hline \multirow{2}{*}{$\begin{array}{l}\text { Acidification } \\
\text { degree }(\mathrm{pH})\end{array}$} & \multicolumn{4}{|c|}{ Renneting extent (\%) } \\
\hline & 20 & 35 & 55 & 74 \\
\hline 4.8 & $8.2 \pm 0.5^{\mathrm{d}, \mathrm{B}}$ & $72.3 \pm 2.4^{\mathrm{e}, \mathrm{C}}$ & $5.0 \pm 1.1^{\mathrm{b}, \mathrm{B}}$ & $0.1 \pm 0.0^{\mathrm{a}, \mathrm{A}}$ \\
\hline 5.0 & $2.6 \pm 0.2^{\mathrm{c}, \mathrm{B}}$ & $4.8 \pm 0.3^{\mathrm{c}, \mathrm{B}}$ & $0.7 \pm 0.2^{\mathrm{a}, \mathrm{A}}$ & $2.8 \pm 0.8^{\mathrm{b}, \mathrm{B}}$ \\
\hline 5.2 & $0.5 \pm 0.1^{\mathrm{b}, \mathrm{A}}$ & $15.5 \pm 1.2^{\mathrm{d}, \mathrm{B}}$ & $20.6 \pm 4.2^{\mathrm{c}, \mathrm{B}}$ & $20.9 \pm 5.1^{\mathrm{c}, \mathrm{B}}$ \\
\hline 5.5 & $0.1 \pm 0.0^{\mathrm{a}, \mathrm{A}}$ & $2.7 \pm 0.3^{\mathrm{b}, \mathrm{B}}$ & $56.2 \pm 10.4^{\mathrm{d}, \mathrm{C}}$ & $3.2 \pm 0.8^{\mathrm{b}, \mathrm{B}}$ \\
\hline 5.8 & $0.1 \pm 0.0^{\mathrm{a}, \mathrm{A}}$ & $0.1 \pm 0.0^{\mathrm{a}, \mathrm{A}}$ & $110.3 \pm 10.7^{\mathrm{e}, \mathrm{B}}$ & $104.9 \pm 13.3^{\mathrm{d}, \mathrm{B}}$ \\
\hline 6.2 & $0.1 \pm 0.0^{\mathrm{a}, \mathrm{A}}$ & $0.1 \pm 0.0^{\mathrm{a}, \mathrm{A}}$ & $115.1 \pm 19.5^{\mathrm{e}, \mathrm{B}}$ & $116.2 \pm 15.0^{\mathrm{d}, \mathrm{B}}$ \\
\hline
\end{tabular}

The time scale of applied deformation reveals how the viscoelastic behavior of milk gels changes with applied stress, providing information on the nature of the bonds in the gel matrix (van Vliet et al., 1991). Frequency analysis for all the samples was done. Results showed that only highly renneted milk gels ( 55 and $74 \%$ ), at $\mathrm{pH} 5.5,5.8$, or 6.2 , had an exponential relationship between $\mathrm{G}^{\prime}$ and frequency, which was used as fingerprinting for comparing different gels (Lucey, 2002). Plotting $\log G^{\prime}$ versus $\log$ frequency resulted in straight lines $\left(R^{2}>0.98\right)$. The slope of the line is related to gel strength; the closer the slope is to zero, the more closely the structure to that of a covalently linked chemical gel (Gunasekaran and Ak, 2000). The slope of $\log G^{\prime}$ versus $\log$ frequency was 0.23 to 0.32 (Table 3), which is similar to those previously reported in rennet-induced milk gels (Mellema et al., 2002). The slope was higher at low $\mathrm{pH}(P<0.05$, Table 3$)$. Twoway ANOVA were performed to determine differences between renneting 55 and $74 \%$, and it was found that no significant differences exist between 55 and $74 \%$ renneted milk gels at the same $\mathrm{pH}(P>0.05)$. Therefore, highly renneted milk gels have more covalent links at high $\mathrm{pH}$.
Higher $\tan \delta$ values favor bond relaxation. The results of the current study revealed that $\tan \delta$ decreased slightly with increasing frequency (Figure 1A and B). Gels had more solid-like characteristics at higher frequency. At the same frequency, the $\tan \delta$ values of $55 \%$ renneted milk gels decreased with increasing $\mathrm{pH}$ (Figure 1A). The tan $\delta$ development of $74 \%$ renneted milk gels was similar to that of $55 \%$ (Figure $1 \mathrm{~A}$ and B). Zoon et al. (1988) reported that low $\tan \delta$ values are representative of less flexible bonds. Our results suggested that at high renneting, less flexible bonds formed with increasing $\mathrm{pH}$.

\section{Structural Properties}

Spontaneous syneresis occurs as a result of local pressure. And it is associated with an unstable gel network and increased whey separation (Walstra et al., 1985). The levels of separated whey in highly renneted milk gels (55 and $74 \%$ ) at different $\mathrm{pH}$ values are shown in Figure 2. High renneting and low $\mathrm{pH}$ contributed to high levels of separated whey. As pH increased, spontaneous whey separation increased and subsequently decreased (Figure 2). These results are consistent with the change

Table 2. Loss tangent of differently acidified and renneted milk gels at $1 \mathrm{~h}^{1}$

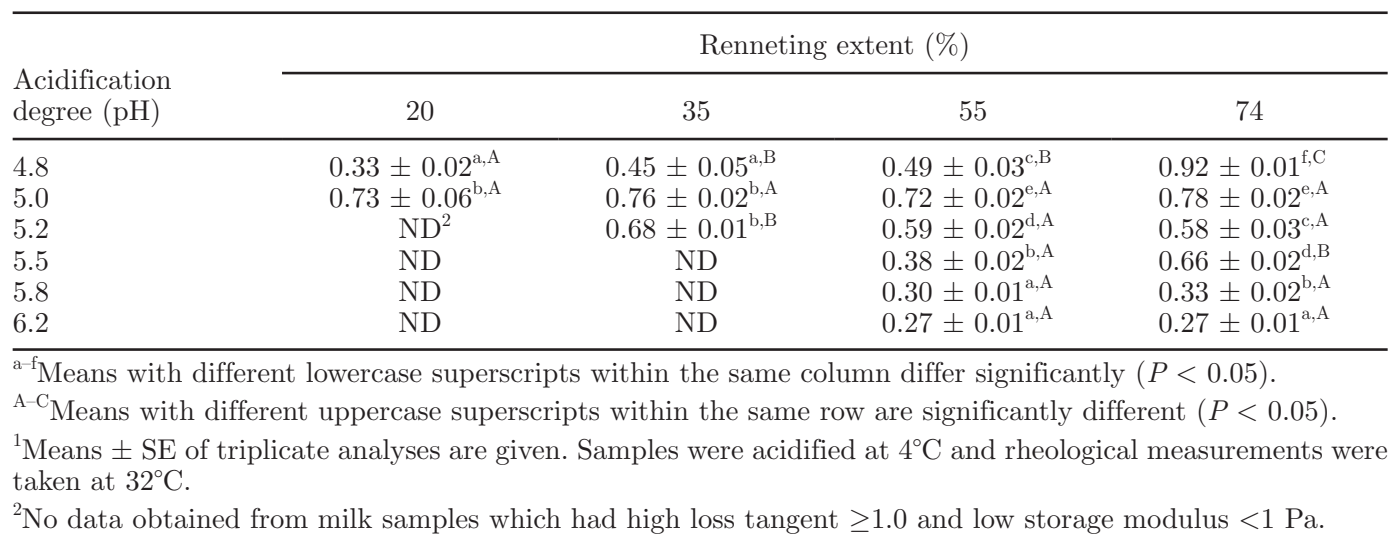


in $\tan \delta$ values as a function of $\mathrm{pH}$ and confirmed that syneresis in combined acid- and rennet-induced gels is highly correlated with $\tan \delta$ values (Castillo et al., 2006b). Therefore, less acidified milk formed a more stable gel network to entrap the serum.

Gel microstructures were examined by confocal scanning laser microscope. Highly renneted milk samples (55 and 74\%) formed homogeneous gels when acidified to $\mathrm{pH} \geq 5.5$ (Figure 3 ). At the same renneting (55 or $74 \%$ ), pH 5.8 and 6.2 induced smaller pores with higher degree of interconnectivity (Figure 3B-F). However, highly renneted milk gels at $\mathrm{pH} 5.5$ had larger clusters and pores (diameter $>30 \mu \mathrm{m}$; Figure $3 \mathrm{~A}$ and D). This result revealed that lower $\mathrm{pH}$ made gels more prone to syneresis than higher $\mathrm{pH}$, which coincides with the $\tan \delta$ results. The gel microstructures may be used to

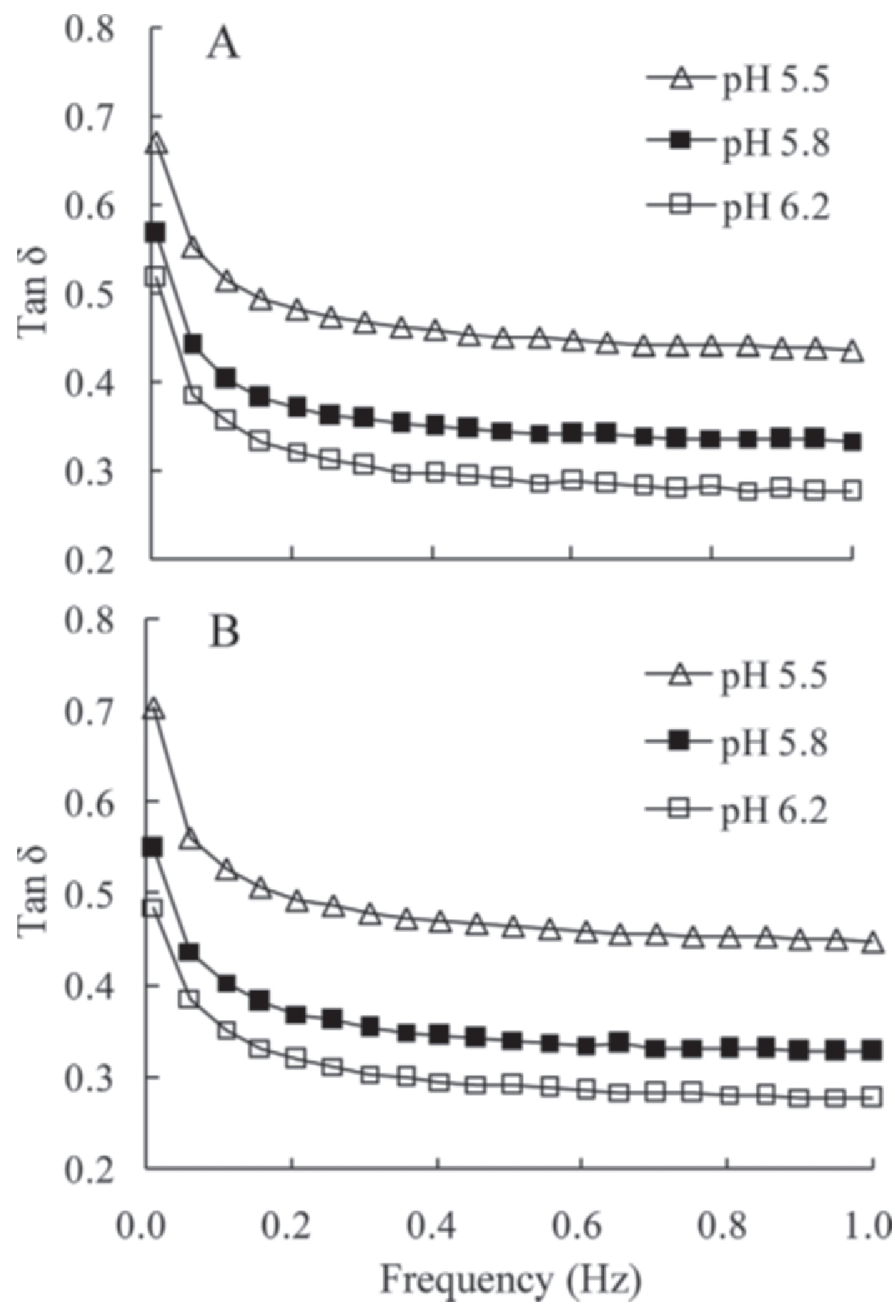

Figure 1. Loss tangent $(\tan \delta)$ as a function of frequency of minimally acidified ( $\mathrm{pH} 5.5,5.8$, and 6.2) and highly renneted milk gels [55 (A) and $74 \%$ (B)] at $1 \mathrm{~h}$. Data obtained from highly renneted milk gels (55 and $74 \%$ ) that had an exponential relationship between storage modulus and frequency are shown.

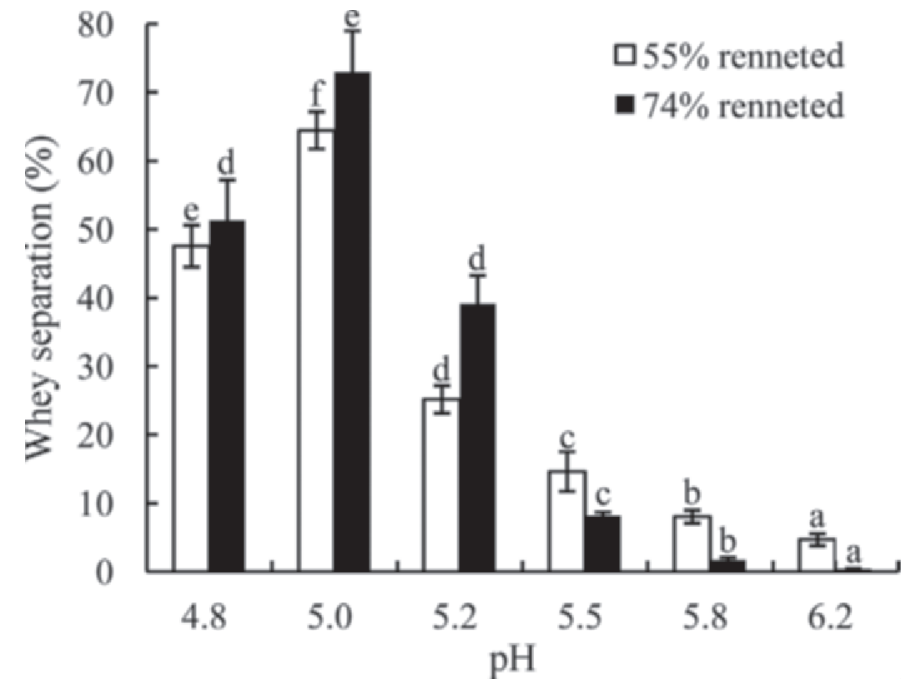

Figure 2. Spontaneous whey separation of acidified and highly renneted milk gels (55 and 74\%). Different letters (a-f) within the same renneting represent a significant difference between the acidification treatments $(P<0.05)$.

explain differences in rheological behavior. Large pores are indicative of the presence of gel strands and stronger fusion of casein particles (Peng et al., 2010).

\section{Identification of Interactions Between Milk Proteins}

Although the method that acidified at $4^{\circ} \mathrm{C}$ and was evaluated at $32^{\circ} \mathrm{C}$ appeared limited, differently acidified and renneted milk constituted a useful model system for studying the effect of changes in chemical interactions during simultaneous renneting and acidification. Figure 4 showed the SDS-PAGE patterns of combined acid- and rennet-induced milk gels that were dispersed in water, EDTA, urea, or SDS. Dissociation agents disrupt specific protein interactions involved in milk gels: EDTA breaks ionic bonds with calcium; urea disrupts hydro-

Table 3. Slope of log storage modulus versus log frequency of highly renneted and minimally acidified milk gels ${ }^{1}$

\begin{tabular}{lcc}
\hline & \multicolumn{2}{c}{ Renneting extent $(\%)$} \\
\cline { 2 - 3 } $\begin{array}{l}\text { Acidification } \\
\text { degree }(\mathrm{pH})\end{array}$ & 55 & 74 \\
\hline 5.5 & $0.320 \pm 0.002^{\mathrm{c}, \mathrm{A}}$ & $0.316 \pm 0.004^{\mathrm{b}, \mathrm{A}}$ \\
5.8 & $0.249 \pm 0.005^{\mathrm{b}, \mathrm{A}}$ & $0.255 \pm 0.005^{\mathrm{a}, \mathrm{A}}$ \\
6.2 & $0.234 \pm 0.003^{\mathrm{a}, \mathrm{A}}$ & $0.241 \pm 0.002^{\mathrm{a}, \mathrm{A}}$ \\
\hline
\end{tabular}

${ }^{\mathrm{a}-\mathrm{c}}$ Means with different lowercase superscripts within the same column differ significantly $(P<0.05)$.

${ }^{A}$ Means with different uppercase superscripts within the same row are significantly different $(P<0.05)$.

${ }^{1}$ Means \pm SE of triplicate analyses are given. Samples were acidified at $4^{\circ} \mathrm{C}$ and rheological measurements were taken at $32^{\circ} \mathrm{C}$. Data were obtained from milk samples that had an exponential relationship between storage modulus and frequency. 


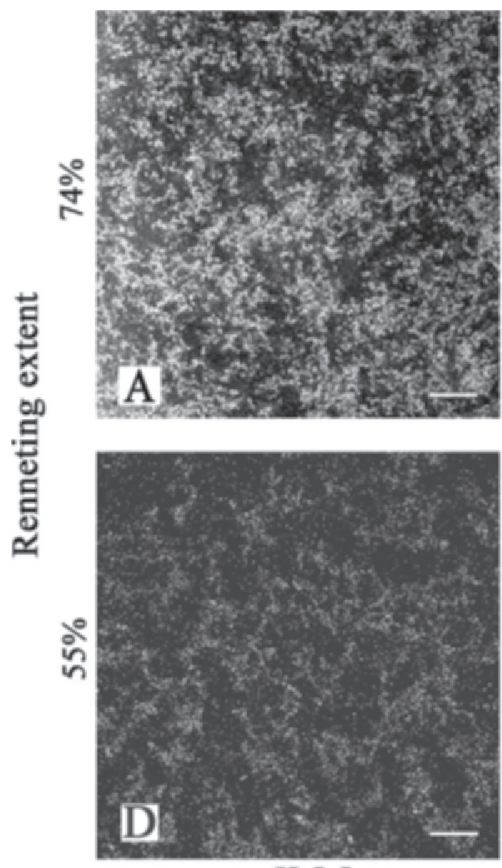

pH 5.5
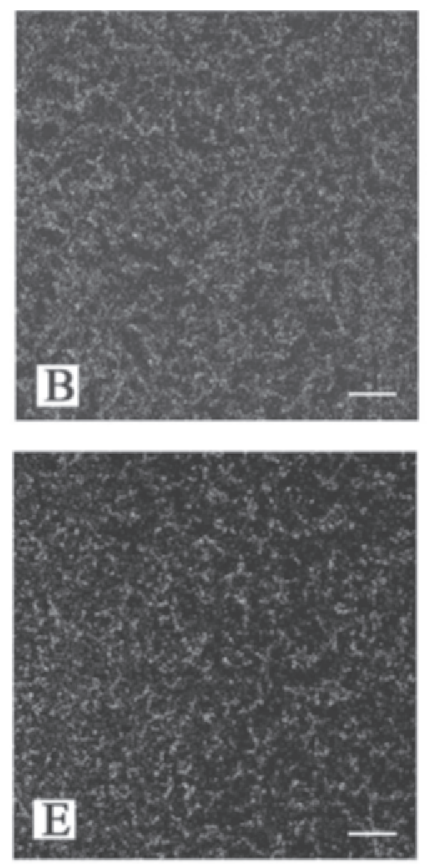

$\mathrm{pH} 5.8$
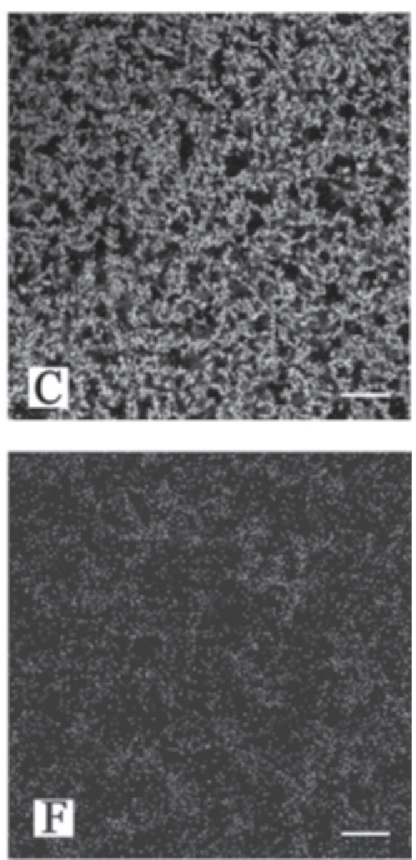

$\mathrm{pH} 6.2$

Acidification degree

Figure 3. Confocal laser scanning micrographs of differently acidified and renneted milk gels. Gels made with 74 (A, B, and C) or $55 \%$ renneted (D, E, and F) milk were subsequently acidified to $\mathrm{pH} 5.5$ (A and D), 5.8 (B and E), or 6.2 (C and F). Proteins are the white areas, whereas the aqueous phase or pores are dark, irregularly shaped areas. Scale bar is $30 \mu \mathrm{m}$.

gen bonds and hydrophobic interactions; SDS disrupts hydrophobic interactions (Lefebvre-Cases et al., 1998). When dispersed in water or EDTA, only whey proteins were present in the supernatant of milk samples $(20 \%$ renneting and $\mathrm{pH} 4.8,35 \%$ renneting and $\mathrm{pH} 4.8,55 \%$ renneting and $\mathrm{pH} 4.8$, and $74 \%$ renneting and $\mathrm{pH} 4.8$ ). However, the amount of dissociated caseins in milk gels increased with increasing renneting and $\mathrm{pH}$ value. Previous studies have reported that EDTA contributed to the dissociation of caseins in rennet-induced milk gels. However, EDTA has no effects on casein dissociation in acid-induced milk gels (Lefebvre-Cases et al., 1998). This suggested that $\mathrm{Ca}^{2+}$ bonds contributed to rennet coagulation but not to acid coagulation. In our results, $\mathrm{Ca}^{2+}$ bonds did not participate in some milk gels $(20 \%$ renneting and $\mathrm{pH} 4.8,35 \%$ renneting and $\mathrm{pH} 4.8,55 \%$ renneting and $\mathrm{pH} 4.8$, and $74 \%$ renneting and $\mathrm{pH} 4.8)$, but contributed in the other milk gels $(35 \%$ renneting and $\mathrm{pH} 5.2,55 \%$ renneting and $\mathrm{pH} 5.5,55 \%$ renneting and $\mathrm{pH} 6.2,74 \%$ renneting and $\mathrm{pH} 5.5$, and $74 \%$ renneting and $\mathrm{pH} 6.2$ ). The $\mathrm{Ca}^{2+}$ bonds were responsible for the protein interactions in the second group of gels. The SDS and urea dissociated all caseins; therefore, hydrophobic interactions and hydrogen bonds were important in those milk gels.

\section{CONCLUSIONS}

We studied the rheological and structural properties of milk gels formed by combinations. Our results showed significant effects of $\mathrm{pH}$ and renneting on the $\mathrm{G}^{\prime}$ and $\tan \delta$ value. The effect of lowering $\mathrm{pH}$ on rheological and structural properties depended on the level of renneting. At high renneting (55 and $74 \%$ ), acidification led to lower $\tan \delta$ values, reduced spontaneous syneresis, and smaller pores. Hydrophobic interactions and hydrogen bonds contributed in the differently acidified and renneted milk gels. Divalent calcium bonds were responsible for interactions in milk gels at high $\mathrm{pH}$, but not for milk gels at low $\mathrm{pH}$. These findings can help processors decide how to balance acid and rennet in the production of combined acid- and rennet-induced gels. However, for real-time assessment of gelation in warm milk during simultaneous renneting and acidification, complementary studies should be performed to investigate the effect of heat treatment.

\section{ACKNOWLEDGMENTS}

This work was supported by the Chinese Universities Scientific Fund (2013QJ034), and the Ministry 


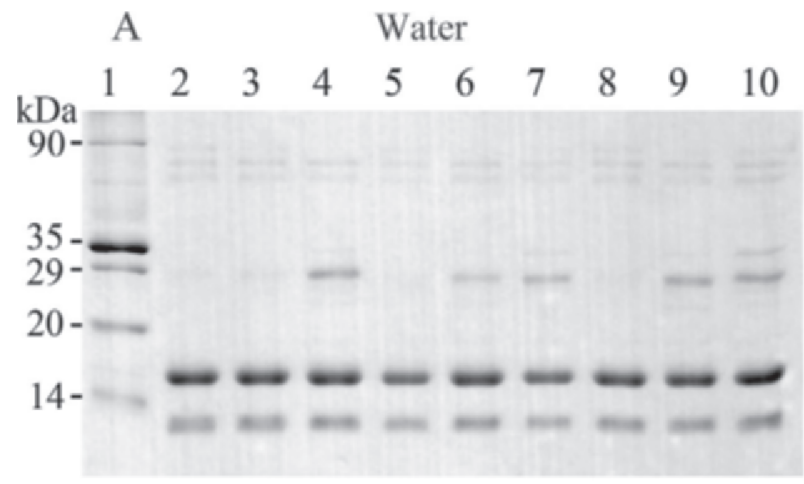

B EDTA
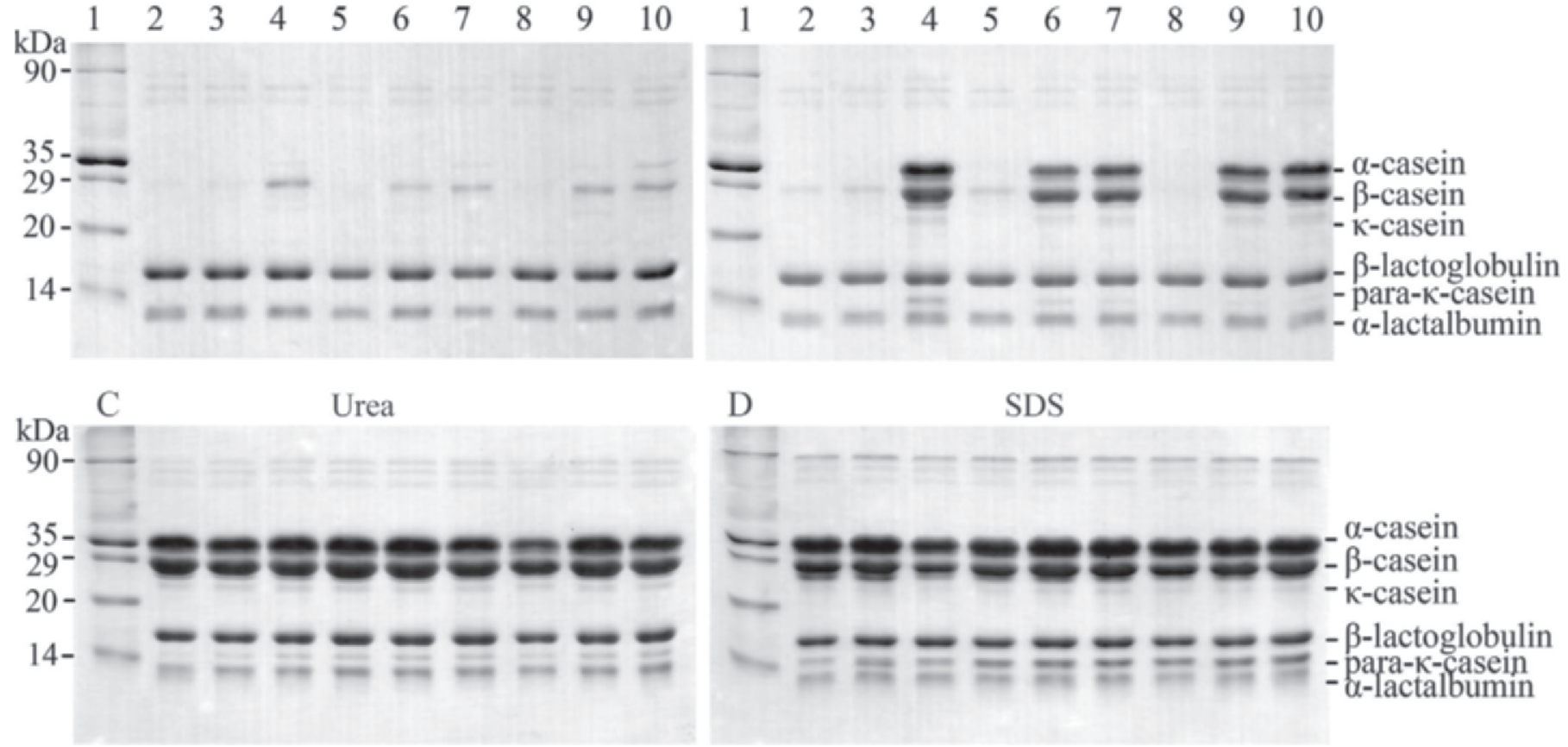

Figure 4. The SDS-PAGE patterns of supernatants obtained from differently acidified and renneted milk gels dispersed in water (A), $2 \mathrm{~m} M$ EDTA (B), $6 M$ urea (C), or $10 \mathrm{~g} / \mathrm{L}$ of SDS (D). Lane 1 contains molecular weight markers. Lanes 2 to 10 contain $20 \%$ renneting and pH 4.8 milk gel, $35 \%$ renneting and $\mathrm{pH} 4.8$ milk gel, $35 \%$ renneting and $\mathrm{pH} 5.2$ milk gel, $55 \%$ renneting and pH 4.8 milk gel, $55 \%$ renneting and pH 5.5 milk gel, $55 \%$ renneting and $\mathrm{pH} 6.2$ milk gel, $74 \%$ renneting and $\mathrm{pH} 4.8$ milk gel, $74 \%$ renneting and pH 5.5 milk gel, and $74 \%$ renneting and $\mathrm{pH} 6.2$ milk gel, respectively.

of Science and Technology of China (Beijing, China; 2012BAD12B08).

\section{REFERENCES}

Alessi, A., A. Fontana, P. Risso, C. Gatti, and M. Pires. 2007. Identification of interactions involved in rennet gel structures using dissociating chemical agents. Colloid Polym. Sci. 285:1281-1286.

Anema, S. G. 2009. Role of colloidal calcium phosphate in the acid gelation properties of heated skim milk. Food Chem. 114:161-167.

Castillo, M., J. A. Lucey, and F. A. Payne. 2006a. The effect of temperature and inoculum concentration on rheological and light scatter properties of milk coagulated by a combination of bacterial fermentation and chymosin. Cottage cheese-type gels. Int. Dairy J. $16: 131-146$.

Castillo, M., J. A. Lucey, T. Wang, and F. A. Payne. 2006b. Effect of temperature and inoculum concentration on gel microstructure, permeability and syneresis kinetics. Cottage cheese-type gels. Int. Dairy J. 16:153-163.

Choi, J., D. S. Horne, and J. A. Lucey. 2007. Effect of insoluble calcium concentration on rennet coagulation properties of milk. J. Dairy Sci. 90:2612-2623.

Cooper, C., M. Corredig, and M. Alexander. 2010. Investigation of the colloidal interactions at play in combined acidification and rennet of different heat-treated milks. J. Agric. Food Chem. 58:49154922.

Dalgleish, D. G. 1979. Proteolysis and aggregation of casein micelles treated with immobilized or soluble chymosin. J. Dairy Res. 46:653-661.

de Kruif, C. G. 1999. Casein micelle interactions. Int. Dairy J. 9:183188.
Gastaldi, E., N. Trial, C. Guillaume, E. Bourret, N. Gontard, and J. L. Cuq. 2003. Effect of controlled kappa-casein hydrolysis on rheological properties of acid milk gels. J. Dairy Sci. 86:704-711.

Gunasekaran, S., and M. M. Ak. 2000. Dynamic oscillatory shear testing of foods-Selected applications. Trends Food Sci. Technol. $11: 115-127$.

Hammelehle, B., P. Schkoda, and H. G. Kessler. 1997. Parameters for coagulation properties of direct acidified milk and for the structure of milk gels. Milchwissenschaft 52:671-674.

Horne, D. S. 1998. Casein interactions: Casting light on the lack boxes, the structure in dairy products. Int. Dairy J. 8:171-177.

Jelen, P., and A. Renzschauen. 1989. Quarg manufacturing innovations and their effects on quality, nutritive-value, and consumer acceptance. Food Technol. 43:74-81.

Laemmli, U. K. 1970. Cleavage of structural proteins during the assembly of the head of bacteriophage T4. Nature 227:680-685.

Le Feunteun, S., and F. Mariette. 2008. Effects of acidification with and without rennet on a concentrated casein system: A kinetic NMR probe diffusion study. Macromolecules 41:2079-2086.

Le Graët, Y., F. Gaucheron, and R. Eacute. 1999. pH-Induced solubilization of minerals from casein micelles: Influence of casein concentration and ionic strength. J. Dairy Res. 66:215-224.

Lefebvre-Cases, E., E. Gastaldi, V. Vidal, S. Marchesseau, A. Lagaude, J. L. Cuq, and B. T. De la Fuente. 1998. Identification of interactions among casein gels using dissociating chemical agents. J. Dairy Sci. 81:932-938.

Li, J., and D. G. Dalgleish. 2006. Controlled proteolysis and the properties of milk gels. J. Agric. Food Chem. 54:4687-4695.

Lin, C., A. Hill, and M. Corredig. 2012. Gelation of mixtures of soymilk and reconstituted skim milk subjected to combined acid and rennet. J. Texture Stud. 43:468-476.

Lucey, J. A. 2001. The relationship between rheological parameters and whey separation in milk gels. Food Hydrocoll. 15:603-608. 
Lucey, J. A. 2002. Formation and physical properties of milk protein gels. J. Dairy Sci. 85:281-294.

Lucey, J. A., P. A. Munro, and H. Singh. 1998. Whey separation in acid skim milk gels made with glucono- $\delta$-lactone: Effects of heat treatment and gelation temperature. J. Texture Stud. 29:413-426.

Lucey, J. A., and H. Singh. 1998. Formation and physical properties of acid milk gels: A review. Food Res. Int. 30:529-542.

Lucey, J. A., M. Tamehana, H. Singh, and P. A. Munro. 2000. Rheological properties of milk gels formed by a combination of rennet and glucono-delta-lactone. J. Dairy Res. 67:415-427.

Lucey, J. A., C. T. Teo, P. A. Munro, and H. Singh. 1997. Rheological properties at small (dynamic) and large (yield) deformations of acid gels made from heated milk. J. Dairy Res. 64:591-600.

Mellema, M., P. Walstra, J. H. J. van Opheusden, and T. van Vliet. 2002. Effects of structural rearrangements on the rheology of rennet-induced casein particle gels. Adv. Colloid Interface Sci. 98:25-50.

Peng, Y., D. S. Horne, and J. A. Lucey. 2010. Physical properties of acid milk gels prepared at $37^{\circ} \mathrm{C}$ up to gelation but at different incubation temperatures for the remainder of fermentation. J. Dairy Sci. 93:1910-1917.

Roefs, S., A. E. A. Degrootmostert, and T. van Vliet. 1990. Structure of acid casein gels. 1. Formation and model of gel network. Colloids Surf. 50:141-159.

Roefs, S., and T. van Vliet. 1990. Structure of acid casein gels. 2. Dynamic measurements and type of interaction forces. Colloids Surf. 50:161-175.
Salvatore, E., A. Pirisi, and M. Corredig. 2011. Gelation properties of casein micelles during combined renneting and bacterial fermentation: Effect of concentration by ultrafiltration. Int. Dairy J. 21:848-856.

Thoma, C., I. Krause, and U. Kulozik. 2006. Precipitation behaviour of caseinomacropeptides and their simultaneous determination with whey proteins by RP-HPLC. Int. Dairy J. 16:285-293.

van Vliet, T., C. M. M. Lakemond, and R. W. Visschers. 2004. Rheology and structure of milk protein gels. Curr. Opin. Colloid Interface Sci. 9:298-304.

van Vliet, T., H. J. M. Vandijk, P. Zoon, and P. Walstra. 1991. Relation between syneresis and rheological properties of particle gels. Colloid Polym. Sci. 269:620-627.

Walstra, P., H. J. M. Vandijk, and T. J. Guerts. 1985. The syneresis of curd. 1. General considerations and literature-review. Neth. Milk Dairy J. 39:209-246.

Zamora, A., A. J. Trujillo, E. Armaforte, D. S. Waldron, and A. L. Kelly. 2012. Effect of fat content and homogenization under conventional or ultra-high-pressure conditions on interactions between proteins in rennet curds. J. Dairy Sci. 95:4796-4803.

Zoon, P., T. van Vliet, and P. Walstra. 1988. Rheological properties of rennet-induced skim milk gels. 1. Introduction. Neth. Milk Dairy J. $42: 249-269$.

Zoon, P., T. van Vliet, and P. Walstra. 1989. Rheological properties of rennet-induced skim milk gels. 4. The effect of $\mathrm{pH}$ and $\mathrm{NaCl}$. Neth. Milk Dairy J. 43:17-34. 